\title{
Beliefs and Practices in the Implementation of Performance Tasks (PETAs): Basis for the Development of Enhancement Program
}

\author{
Shiela Marie B. Masaoay ${ }^{1}$, Rodrigo A. Litao ${ }^{2}$ \\ ${ }^{1}$ Lecturer, Institute of Education, Far Eastern University, Philippines. \\ ${ }^{2}$ Associate Professor, Assistant Principal for Curriculum and Instruction, University of Santo Tomas, \\ Philippines.
}

\begin{tabular}{|c|c|}
\hline Article Info & Abstract \\
\hline $\begin{array}{l}\text { Article history: } \\
\text { Received: } 19 \text { May } 2021\end{array}$ & $\begin{array}{l}\text { Purpose: The study aimed to determine the respondents' beliefs and } \\
\text { practices in the implementation of PETAs. }\end{array}$ \\
\hline $\begin{array}{l}\text { Revised: } 12 \text { July } 2021 \\
\text { Accepted: } 14 \text { July } 2021\end{array}$ & $\begin{array}{l}\text { Approach/Methodology/Design: This is a quantitative study wherein } \\
\text { statistical treatments such as mean and Structural Equation Modelling }\end{array}$ \\
\hline $\begin{array}{l}\text { Keywords: } \\
\text { Performance Tasks, } \\
\text { Assessment, } \\
\text { K-12 Program, }\end{array}$ & $\begin{array}{l}\text { (SEM) are utilized. A self-made questionnaire was used that underwent a } \\
\text { validity and reliability test. The participants of this study were selected from } \\
\text { the seven Senior High School with a tertiary level in the University belt area } \\
\text { in the city of Manila. }\end{array}$ \\
\hline $\begin{array}{l}\text { Beliefs, } \\
\text { Practices }\end{array}$ & $\begin{array}{l}\text { Findings: Results indicated that the commonly held beliefs of the } \\
\text { respondents are consistent with the premises of PETAs described by }\end{array}$ \\
\hline $\begin{array}{l}\text { Paper Type : } \\
\text { Research Article }\end{array}$ & $\begin{array}{l}\text { Department of Education and by the literature reviewed in this study. This } \\
\text { shows that teachers implement PETAs that are real-life applications of } \\
\text { learning. Even though there are difficulties in implementing this type of }\end{array}$ \\
\hline Corresponding Author: & $\begin{array}{l}\text { assessment the respondents apply it in their classes not only because it is } \\
\text { mandated by the Department of Education but because they have high }\end{array}$ \\
\hline Shiela Marie Masaoay & beliefs in PETAs being a valid and meaningful way to assess learning. \\
\hline Email: & $\begin{array}{l}\text { Practical Implications: The study can serve as a basis for the development } \\
\text { of an enhancement program for proper implementation and management of }\end{array}$ \\
\hline smasaoay@feu.edu.ph & PETAs for senior high school teachers. \\
\hline & $\begin{array}{l}\text { Originality/value: Much research may have been conducted regarding } \\
\text { PETAs particularly in the foreign setting, but there is much dearth of } \\
\text { literature on this topic in the Philippines particularly in the Senior High } \\
\text { School setting. It is expected that most of the research efforts of the } \\
\text { Department of Education will focus on studying the many aspects of the K to } \\
12 \text { programs such as the efficacy of the curriculum and instruction. } \\
\text { Interestingly, the implementation of the PETAs could be one of those aspects } \\
\text { that need empirical data for policymaking in the future. }\end{array}$ \\
\hline
\end{tabular}

\section{Introduction}

In 2012, the Philippines launched its $\mathrm{K}$ to 12 programs, a comprehensive basic education reform program. "Discussion Paper on The Enhanced K+12 Basic Education Program" (2010) stated that the program is an enhanced curriculum that is decongested providing more time for students to master the competencies that the $21^{\text {st }}$-century market needs. Furthermore, Senior High School students will be more college-ready, employable or capable of starting their own 
business, and senior high school graduates can meet the academic requirements needed as a foreign student in case they go abroad. The new curriculum concentrates on the "holistic development" of the learner which has also been quoted by Magno \& Pioyang (2016). It highlights the "outcome-based approach" for better-preparing students for higher education and providing them with skills in entrepreneurship and mid-level job skills. The curriculum is anchored on the principles of inclusiveness, growth and development, and learning and assessment, which is said to be a fundamental element of the program.

According to the "Policy Guidelines on Classroom Assessment for the $\mathrm{K}$ to 12 Basic Education Program" (2015), there are two types of assessment that should be employed: formative assessment and summative assessment. Formative assessment is given during the lesson or grading period. It is intended to determine how the students cope with the lesson and what their difficulties are. It is in the form of a short quiz, written exercises, and group works. On the other hand, summative assessment is conducted at the end of the unit or the end of the quarter. It measures how learners use and apply what they have learned. It is in the form of written work which is comprised of long tests and other written outputs such as quarterly, midterms, and final examinations. Another component of the Summative test is the Performance Task or PETA. Department of Education requires PETA for all subject areas. McTighe (2017) emphasized that PETAs are regularly used in certain disciplines, such as visual and performing arts, physical education, and career technology where performance is the natural focus of instruction. However, such tasks can and should be used in every subject area and at all grade levels as stated in the DepEd Order No. 8 s. 2015. PETAs enable learners to demonstrate what they have learned at the end of the lesson episode and what are they able to do in various ways. They can create or innovate products or carry out tasks. Skill demonstration, oral performances, multimedia presentations, and research projects are some of the examples of PETAs. Students either accomplish it individually or in groups. It also offers opportunities for students to demonstrate and integrate the knowledge, understanding, and skills that they have learned in a particular real-life situation. It is given several times during the quarter at the end of the lesson focusing on a topic/skill lesson ("Policy Guidelines on Classroom Assessment for the K to 12 Basic Education Program”, 2015).

As stipulated in the "Policy Guidelines on Classroom Assessment for the $\mathrm{K}$ to 12 Basic Education Program" (2015), PETAs should be implemented in the classroom to produce graduates that are capable of applying the knowledge that they learned. Thus, teachers are faced with the challenge of implementing PETAs with the desired competency so as not to sacrifice the students' learning. Lack of competency and knowledge as regards the premises of PETAs may lead to failure of the attainment of the goals of $\mathrm{K}$ to 12 programs. If PETAs are not appropriate or implemented properly due to teachers' lack of knowledge about the premises of PETAs, there may be a failure in measuring the students' capabilities. Thus, some of the goals of K-12 may not be possibly attained. Thus, proper implementation of PETAs in Senior High School should be looked into. As per DepEd Memorandum, PETAs are important components for assessing students' learning for the Senior High School level. It has the highest percentage weight allotment in the grading system. This only implies that PETAs are the most important and are the highlight of all the activities in every quarter in the 
school calendar. However, no definite guidelines in implementing them are provided, which might mean that teachers could face confusion in terms of their knowledge of its premises and proper implementation. Hence, this study attempts to bridge such a gap. This study is also worth undertaking because the Department of Education has just completed the implementation of the first batch of the Senior High School graduates during the school year 2018-2019. Hence, the data that the study yielded may help in providing feedback about the quality of the said program particularly on the implementation of PETAs at the Senior High School level in the Philippines.

This study aims to determine the beliefs and practices of Filipino Senior High School teachers as regards the premises and implementation of Performance Tasks. It specifically seeks to answer the following research questions: (1) What are the teacher respondents' a) beliefs about the premises of PETAs, b) common practices, and c) difficulties in the implementation of PETAs? (2) Is there a positive correlation between the respondents' beliefs about the premises of PETAs and common practices for their implementation? This study is anchored on two prominent educational theories: namely, Constructivism and Zone of Proximal Development.

In Constructivism, learners construct their knowledge, and this reminds us of the importance of prior knowledge and social interaction in the learning process (Santrock, 2011). This idea was supported by Tria, Limpingco, and Jao (2008) when they stated that problem-solving, reasoning, critical thinking, and the active use of knowledge were the goals of constructivist instruction.

The constructivist view of Jean Piaget, Lev Vygotsky, and Jerome Bruner were utilized in this study. Piaget stressed that when students are active, they learn best and seek solutions for themselves (Santrock, 2011). On the other hand, Vygotsky's Social Learning theory believed that psychological phenomena arose out of social interaction. In a learning process, the teacher facilitates by providing information and organizing activities for learners to discover their learning and only acts as facilitators. Thus, Constructivism involves learners with situations wherein they can create and develop their knowledge by asking questions, summarizing ideas, and collaborating with others (Liu \& Chen, 2010). This is supported by Jerome Bruner's constructivist view where there is a strong emphasis on discovery learning where adults transform the classroom into a learning environment that offers purposeful opportunities to learn through discovery. Also, scaffolding wherein the teacher supports the learners as they work with their task is an effective way to motivate them (Macblain, 2018).

The theoretical basis of the assessment practice for the $\mathrm{K}$ to 12 Basic Education Program is the learners' Zone of Proximal Development (ZPD). Vygotsky explains that the ZPD is "the distance between the actual developmental level as determined by independent problem solving and the level of potential development as determined through problem-solving under adult guidance, or in collaboration with more capable peers" (as cited in McLeod, 2019).

The Zone of Proximal Development theory suggests that teachers' interventions such as clear examples, additional instruction and prompts would help students move from being 
dependent learners to independent learners with mastery of the lesson. Vygotsky argued that assessment should determine the child's ZPD and use this as the focus of the teacher's teaching (as cited by Santrock, 2011). In Bachelor's (2015) view, ZPD can be utilized by contemporary educators as they work together with students to facilitate learning.

The Department of Education has utilized the Zone of Proximal Development theory in defining and setting the essentials of Performance Assessment for the Senior High School, which is stipulated in DepEd Order No. 8 s. 2015.

\section{Literature Review}

\section{Assessment}

Assessment of student achievement is one of the key elements of teaching (Letina, 2015; Sebate, 2011). It is not only complementary and should be taken into account from the beginning of the teaching-learning planning stage (Sebate, 2011). It has an important objective of finding the knowledge that has been learned that cannot be seen and must be practiced with a proactive, practical approach that students can complete (Carper, 2012). R. Rosaroso and N. Rosaroso (2015) added, "Teachers view assessment as a comparison of student's performance from given criteria. Students, on the other hand, perceive assessment as a room for improvement and an avenue for further learning" (p. 72). According to Mussawy (2009), Opre (2015) and Sebate (2011), assessment results inform teachers not only on the progress of the students but also on the effectiveness of their instructions. The outcomes of the students' examination have a huge impact on the instructional practice of the teachers. Burke (2005) agrees that the purpose of the assessments is to provide students with information, evaluate their knowledge and understanding of key concepts and standards, and guide the educational process. It should be noted that even the "Policy Guidelines on Classroom Assessment for the K to 12 Basic Education Program" (2015) indicated that assessment enables teachers to monitor the progress of students and assessment informs the students and their parents of their progress. Furthermore, Assessment is defined as ' a process used to track the progress of learners ' in terms of learning standards and skills development in the 21 st century.

When implemented properly, assessment tools and strategies can have a positive impact on key aspects of the reform of education that allows a broader range of skills to be assessed instead of mere content recall. These strengthen the students' engagement as they also assess their performance and students' acquisition of the 21st-century skills (Moss, Girard, \& Haniford, 2006). According to Brown, Kennedy, Kwan Fok, Chan and Yu (2009) teachers, being the implementers of assessment, are key persons in the teaching process. It is important to know their understanding of assessment and to be able to determine their practices. Sebate (2011) agreed with this when he cited that teachers' understanding of assessment will determine how they assess inside the classroom making the beliefs of teachers in the assessment process an evoking topic. Thus, the examination of teacher beliefs provides a means of understanding the relationship between beliefs and student outcomes, insight into 
teacher classroom practices and pedagogy and the multifaceted nature of the entire educational environment (Muis \& Foy, 2010; Opre, 2015)

\section{Assessment in K to 12 Program in the Philippines}

According to Okabe (2013), the Philippines meet global standards of secondary education through $\mathrm{K}$ to 12 program. In senior high school, the additional two years are hoped to give students more time to develop the skills and acquire the necessary learning competencies that the 21 st century demands. Its assessment process takes on diverse approaches considering the age of the students and the system of implementing the SHS program.

The table 1 shows the Weight of Components of Senior High School from the "Policy Guidelines on Classroom Assessment for the K to 12 Basic Education Program" (2015) learners from Grades 1 to 12 are graded on Written Work, Performance Tasks, and Quarterly Assessment every quarter. These three are given specific weights that vary according to the nature of the learning area. It can be noted that PETAs have been given the highest weight. The reason behind this can be explained by Magno and Piosang (2016) in their article stating that assessment in the $\mathrm{K}$ to 12 must become more functional to address the demands of the workplace and community. Assessment takes a significant role in providing students with the 21 st century skills.

\section{Performance Assessment/ Performance Task}

Table 1 : Weight of Grade Components of Senior High School

Technical-Vocational and Livelihood (TVL)/

Academic Track Sports/Arts and Design Track

\begin{tabular}{lccccc}
\hline Assessment & $\begin{array}{l}\text { Core } \\
\text { subjects }\end{array}$ & $\begin{array}{l}\text { All other } \\
\text { subjects }\end{array}$ & $\begin{array}{l}\text { Work Immersion/ } \\
\text { Research/Business } \\
\text { Enterprise Simulation } \\
\text { Exhibit/ Performance }\end{array}$ & $\begin{array}{l}\text { All } \\
\text { other } \\
\text { subjects }\end{array}$ & $\begin{array}{l}\text { Work Immersion } \\
\text { Research/Exhibit } \\
\text { Performance }\end{array}$ \\
\hline Written Work & $25 \%$ & $25 \%$ & $35 \%$ & $20 \%$ \\
Performance Task & $\mathbf{5 0 \%}$ & $\mathbf{4 5 \%}$ & $\mathbf{4 0 \%}$ & $\mathbf{6 0 \%}$ \\
Quarterly Assessment & $25 \%$ & $30 \%$ & $25 \%$ & $20 \%$
\end{tabular}

According to Moqbel (2014) Performance Assessment entails students to create or perform tasks, develop portfolios, journals, diaries, and projects. Stecher (2010) agreed that performance assessment covers a very wide range of activities. Grabin noted that Performance-based tasks are tasks that require students to employ the knowledge and skills they have acquired by creating a product or delivering a performance (as cited by Moqbel, 2014; Bekiroglu, 2008). In another study, Abbott and Wren (2016) agreed that performance assessment is an effective way to evaluate higher-order thinking skills. 
According to Garcia (2007), there is no consensus regarding assessment terminology. In related literatures, the definition of Performance Assessment and Performance Tasks (PETAs) may be overlapping but this was clarified by Stecher (2010). He pointed the difference between Performance Assessment and Performance Tasks. He defined that: A performance assessment is a collection of performance tasks. On the other hand, Performance Tasks (PETAs) is a structured situation in which stimulus materials and information, or action requests are submitted to an individual who generates a response that can be assessed using explicit standards. In summary, according to Killen, all assessments are considered PETAs when it requires students to demonstrate their ability to remember, understand, apply, analyze, evaluate and create different forms of knowledge (as cited in Sebate, 2011).

\section{Methodology and Procedures}

In this study, the quantitative approach was employed wherein a survey was conducted to determine the beliefs, practices, and difficulties of the teacher respondents in implementing PETAs. Additionally, the positive correlation between the beliefs and practices of the teacher in implementing PETAs is stipulated in the study. The participants were selected from the seven Senior High School with a tertiary level in the University belt area in the city of Manila.

This study made use of a self-made questionnaire. The researcher developed a survey questionnaire consisting of three parts: a) Beliefs survey part consisting of items about the respondents' beliefs in the premises of PETAs; c) Practices survey part consisting of items about the respondents' practices in the implementation of PETAs; and d) Difficulties survey part, in which the respondents ticked the listed difficulties in the implementation of PETAs. The beliefs and practices parts of the survey questionnaire are anchored on the theories of Constructivism, Zone of Proximal Development, and DepEd Order No. 8, s. 2015.

The researcher-made instrument was pilot tested on a group of 40 senior high school teachers in one of the schools in Manila. Internal consistency or reliability of the items in the instruments was tested through Cronbach Alpha. Results showed that the instrument on Respondents' Beliefs about the Premises of PETAs received a Cronbach Alpha of 0.786 with the interpretation of acceptable (Tavakol \& Dennick, 2011) while the Common Practices as Regards Implementation of PETAs received a Cronbach Alpha of 0.844 with the interpretation of good (Tavakol \& Dennick, 2011). The instrument underwent another reliability test after the actual gathering of data. The Respondents' Beliefs about the Premises of PETAs yielded a Cronbach Alpha of .854 while the Common Practices as Regards Implementation of PETAs yielded a Cronbach Alpha of .832. Interpretation for both is good (Tavakol and Dennick, 2011).

The following were used to analyze the data:

a. Descriptive Statistics- Mean was used to determine the frequency of occurrence of study respondents' beliefs and practices in the implementation of PETAs while Percentage (\%) was used to measure the difficulties of the teachers in the implementation of PETAs. The items 
with the highest percentage were deemed as the most difficult practice in the implementation of the PETAs.

b. Structural Equation Model (SEM) is a multivariate technique of statistical analysis used to analyze structural relationships. This is a combination of factor analysis and analysis of multiple regression and is used to analyze the structural relationship between measured variables and latent constructs ("Structural Equation Modelling”, n.d.).

\section{Results and Discussion}

What are the teacher respondents' common a) beliefs about the premises of PETAs, b) common practices, and c) difficulties in the implementation of PETAs?

Table 2: Teacher respondents' common beliefs about the premises of PETAs

\begin{tabular}{|c|c|c|c|c|}
\hline Beliefs & Rank & Mean & $\begin{array}{c}\text { Std. } \\
\text { Deviation }\end{array}$ & $\mathrm{N}$ \\
\hline $\begin{array}{l}\text { PETA has several forms, such as performance-based tasks, } \\
\text { portfolios, journals, diaries, projects, etc. }\end{array}$ & 1 & 1.33 & 0.5597 & 300 \\
\hline $\begin{array}{l}\text { PETA evidence appears in many different forms; it can } \\
\text { involve solving realistic problems, oral or psychomotor } \\
\text { skills. }\end{array}$ & 2 & 1.366 & 0.5144 & 300 \\
\hline $\begin{array}{l}\text { PETA is a type of assessment that focuses on } \\
\text { demonstration of skills or producing an output. } \\
\text { PETA refers to a variety of tasks and in situations in which } \\
\text { students can demonstrate }\end{array}$ & 3 & 1.381 & 0.5563 & 300 \\
\hline their understanding of the lesson and apply & 4 & 1.385 & 0.5863 & 300 \\
\hline \multicolumn{5}{|l|}{ Knowledge and skills in a variety of contexts. } \\
\hline $\begin{array}{l}\text { PETA includes a very wide range of activities such as } \\
\text { writing an analysis, conducting laboratory investigations } \\
\text { and other related hands-on activities. }\end{array}$ & 5 & 1.391 & 0.5523 & 300 \\
\hline $\begin{array}{l}\text { Scoring rubrics support learning and is a must in } \\
\text { implementing PETA. }\end{array}$ & 6 & 1.393 & 0.5519 & 300 \\
\hline $\begin{array}{l}\text { PETA requires more time to design and evaluate, and more } \\
\text { objectivity is needed in scoring. }\end{array}$ & 7 & 1.443 & 0.5578 & 300 \\
\hline $\begin{array}{l}\text { The rubric used in scoring PETA identifies all the needed } \\
\text { attributes and degrees of completeness of each attribute. }\end{array}$ & 8 & 1.453 & 0.572 & 300 \\
\hline PETA focuses on the processes and products of learning. & 9 & 1.477 & 0.6184 & 300 \\
\hline $\begin{array}{l}\text { PETA is interdisciplinary; it can be integrated with other } \\
\text { learning areas. }\end{array}$ & 10 & 1.487 & 0.6132 & 300 \\
\hline $\begin{array}{l}\text { PETA allows learners to show what they had learned and } \\
\text { what they are able to do in diverse ways. }\end{array}$ & 11 & 1.517 & 0.5924 & 300 \\
\hline $\begin{array}{l}\text { PETA encompasses many skills and usually has a direct } \\
\text { application to real tasks. }\end{array}$ & 12.5 & 1.527 & 0.6128 & 300 \\
\hline PETA gives feedback to both teachers and students. & 12.5 & 1.527 & 0.6128 & 300 \\
\hline PETA scores given to students are not always the same. & 14 & 1.584 & 0.645 & 300 \\
\hline $\begin{array}{l}\text { Small or enabling PETAs are necessary so that the students } \\
\text { can perform the culminating PETA proficiently. }\end{array}$ & 15 & 1.638 & 0.6034 & 300 \\
\hline PETA is always aligned to standards. & 16 & 1.654 & 0.7301 & 300 \\
\hline $\begin{array}{l}\text { PETA often takes place over time, leading to tangible } \\
\text { product or observable performance }\end{array}$ & 17 & 1.721 & 0.7125 & 300 \\
\hline $\begin{array}{l}\text { PETA requires students to be involved in extensive } \\
\text { assessments especially at the formative stage. }\end{array}$ & 18 & 1.758 & 0.6243 & 300 \\
\hline PETA does NOT have exact right or wrong answers. & 19 & 1.815 & 0.8196 & 300 \\
\hline
\end{tabular}


Scores are determined by the teacher through the degrees to which students have achieved or attained the standard or objective.

PETA implementation is intensive and time consuming.

PETA demonstrates alignment of standards by requiring more tasks and work samples.

Not all PETAs are authentic assessment or likened to real life tasks.

PETA does NOT always require students to produce an output or product.

$\begin{array}{llll}20 & 1.828 & 0.7501 & 300 \\ 21 & 1.848 & 0.7039 & 300 \\ 22 & 2.268 & 1.4148 & 300 \\ 23 & 2.508 & 0.9471 & 300 \\ 24 & 2.669 & 1.0153 & 300\end{array}$

PETA is NOT always applicable in all subject areas.

The weighted mean of the Beliefs about the premises of PETAs was computed and results showed that the top five beliefs are the following: Rank 1- PETA has several forms, such as performance-based tasks, portfolios, journals, diaries, projects, etc.; Rank 2- PETA evidence appears in many different forms; it can involve solving realistic problems, oral or psychomotor skills; Rank 3- PETA is a type of assessment that focuses on the demonstration of skills or producing an output; Rank 4 PETA refers to a variety of tasks and situations in whichstudents can demonstrate their under standing of the lesson and apply knowledge and skills in a variety of contexts and; Rank 5PETA includes a very wide range of activities such as writing an analysis, conducting laboratory investigations and other related hands-on activities.

These top five beliefs of the respondents support the view of Garcia (2007) and Metin (2010) that PETAs give focus on problem-solving, decision-making and critical thinking; Results also support the view of Letina (2015) that assessment should fit into real-life complex situations or real-life problems. Respondents also agree that with what Grabin has asserted that PETAs has several forms, such as performance-based tasks, portfolios, journals, diaries, projects as identified (as cited by Moqbel, 2014; Bekiroglu, 2008). Their beliefs also validate Sebate (2011) when he defined assessment as a collection of information of the students learning before, during or after teaching (Sebate, 2011). The teachers' beliefs are the same with the view of Wren (2009) that performance assessment is student-centered and targets higher-order thinking skills and other $21^{\text {st }}$ century skills.

Table 3: Respondents' common practices in the implementation of PETAs

\begin{tabular}{lllll} 
Practices & Rank & Mean & Std. & Deviation \\
& & & \\
& & 1 & 1.233 & .4392 \\
\hline $\begin{array}{l}\text { I design a PETAs which require the students to demonstrate } \\
\text { the knowledge, skills and values taught to them. }\end{array}$ & & & 300 \\
$\begin{array}{l}\text { I develop PETAs that make the class interactive and facilitates } \\
\text { exchange of ideas and performances. }\end{array}$ & 2 & 1.282 & .4710 & 300 \\
$\begin{array}{l}\text { I involve students in the learning process individually or in } \\
\text { collaboration with teammates in doing their PETAs. }\end{array}$ & 3 & 1.288 & .5149 & 300 \\
I give additional instruction and prompts that would help & 4 & 1.39 & .5588 & 300
\end{tabular}


learner in doing their PETAs.

I give the students the freedom to express their learning in

5

1.407

.5559

300

appropriate and diverse ways

I develop performance criteria that are based on attributes of a 6

1.443

.5652

300

product or performance which demonstrate mastery.

I give my feedback on the students' PETAs such as the

7

1.447

.5924

300

strengths, weaknesses etc. after their presentation.

I develop explicit performance criteria which measure the

skills.

I only construct PETAs that are challenging yet achievable

9

1.492

.6085

I ask relevant questions about the lesson that can help in

doing their PETAs.

I give time limit during performances or demonstration of a task.

I list the knowledge and skills I wish to have students learn as a

result of completing a task

I turn the classroom into a setting of exploration and discovery. 13

I develop checklists that indicate the presence or absence of an 14

$1.659 \quad .7017$

attribute which includes how many points each attribute is worth.

I collaborate with other teachers teaching other subjects for

I give two - four PETAs during the quarter.

I always conduct the presentation of PETAs inside the

I always require my students to use technology in developing

I do not interrupt or ask questions during the students'

I sometimes invite other teachers to give grade to the PETAs of

I do not let students choose their own group mates in doing

I do not always give immediately the result or score of students 
The weighted mean of the Common Practices as regards the implementation of PETAs were computed and the results showed that the top five common practices are the following: Rank 1- I design a PETAs which requires the students to demonstrate the knowledge, skills and values taught to them; Rank 2 - I develop PETAs that make the class interactive and facilitates the exchange of ideas and performances; Rank 3 - I involve students in the learning process individually or in collaboration with teammates in doing their PETAs; Rank 4 - I give additional instruction and prompts that would help students move from a dependent learner to an independent learner in doing their PETAs; and Rank 5 - I give the students the freedom to express their learning in appropriate and diverse ways.

According to Stecher (2010), there are no specific choices in giving PETAs. Students are free to construct their responses. Because of this, there is the exchange of ideas in the classroom especially that PETAs are often done by the group. We can relate this to the Constructivism of Lev Vygotsky which emphasizes the social contexts of learning and the construction of knowledge through social interaction (Santrock, 2011).

In addition, the giving of clear instructions as one of the practices in implementing PETAs supports what Stecher (2010) pointed out that a direction is part of the stimulus since PETAs are planned situations in which stimulus materials and a demand for output are presented to the students. This practice is also consistent with the Zone of Proximal Development theory, suggesting that teachers' interventions such as clear examples, additional instruction and prompts would help students move from being dependent learners to independent learners with mastery of the lesson. Assessments are done through the facilitation of the teacher that allows students to construct meaning for themselves (Bachelor, 2015).

Table 4: Difficulties in the implementation of PETAs

\section{Difficulties}

Rank

Too many class interruptions due to meetings, required reports, trainings, other teachers' extra-curricular activities required etc.

Time constraint in implementing inside the classroom

PETA is time consuming to prepare or construct the activities

Large student population per class

Subjectivity in terms of giving grades

Lack of facilities and technological resources like multimedia resource

Complaints from parents about rehearsals and group meetings outside school

Difficult to invite other teachers to rate students' PETAs

$\begin{array}{lll}1 & 194 & 65 \% \\ 2 & 160 & 53 \% \\ 3 & 152 & 51 \% \\ 4 & 148 & 50 \% \\ 5 & 129 & 43 \% \\ 6 & 96 & 32 \% \\ 7 & 91 & 30 \% \\ 8 & & \\ & 87 & 30 \%\end{array}$

66

Copyright (C 2021, Middle Eastern Journal of Research in Education and Social Sciences (MEJRESS), Under a Creative Commons Attribution 4.0 
Difficult to align PETAs with the content and performance

Difficulty in managing students' behavior during implementation of PETAs

Lack of support from the administrators when it comes to PETAs

that are to be implemented outside the classroom

Limited knowledge in constructing rubrics

Using too many forms in recording scores

Lack of knowledge on constructing PETAs
10

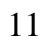

12

13

14
82

72

57

53

14
$27 \%$

$24 \%$

$19 \%$

$18 \%$

$5 \%$

It can be seen from the table that the top five difficulties of the respondents in implementing PETAs are the following: Rank 1- Too many class interruptions due to meetings, required reports, trainings, other teachers' extra-curricular activities required, etc.(65\%); Rank 2Time constraint in implementing inside the classroom (53\%); Rank 3- PETA is timeconsuming to prepare or construct the activities (51\%); Rank 4- Large student population per class ( 50\%; Rank 5- Subjectivity in terms of giving grades (43\%). Other difficulties in the implementation of PETAs as indicated by the respondents aside from the choices given are class suspensions, tardiness of the students, non-participation of all members in doing the PETAs but they receive the same grade, free-loader students who are not monitored, too many other tasks along with PETAs, diverse learners' needs, students demanding higher score even the teacher is just basing on the rubrics, integration of PETAs with other subjects should not be mandatory, some PETAs overlap with students other schedules of activities such as classes and co-curricular requirements; and students' limited life experiences which limits their ideas and creativity.

Time management is difficult for the teachers because of class interruptions due to meetings, required reports, trainings, and other teachers' extra-curricular activities required, which make the preparation and implementation of PETAs more difficult. Large student population also affects the time of implementation since the teacher is required to monitor all students' performance. In addition, PETAs are done in different forms; thus, it requires more time to be done and presented inside the classroom. These results show that the huge factor in causing the top four difficulties is time, which also surfaced in some previous studies (Letina ,2015; Al-Nouh, et al., 2014; Guerin, 2010; Yang, 2007; Metin, 2013; Elliott \& Roach, 2007; Gonzalez, 2014; R. Rosaroso \& N. Rosaroso, 2015).

The fifth difficulty from the result is subjectivity in terms of giving grades, which was also found out by Al-Nouh, et al., (2014) and Yang (2007). It was mentioned in their studies that alternative assessments including PETAs are subjective and hard to use. Subjectivity in terms of giving grades can be attributed to a lack of guidelines for the proper implementation of PETAs (Letina, 2015). Since this type of assessment does not have exact correct or incorrect answers, scores are given based on the degree to which the students have achieved the skills 
being required. Such difficulty can be addressed, however, by the use of rubrics. Rubrics are tools used to rate the students' proficiency in their PETAs (Brualdi, 2000; Bekiroglu, 2008). This is supported by Munif, Lukluk \& Fauziati, Endang \& Marmanto, Sri. (2019), according to them the best tools that is used to assess in performance assessment is the rubric because it covers all of the students descriptions as their work results (p. 526).

5. Is there a positive correlation between the respondents' beliefs about the premises of PETAs and common practices for their implementation?

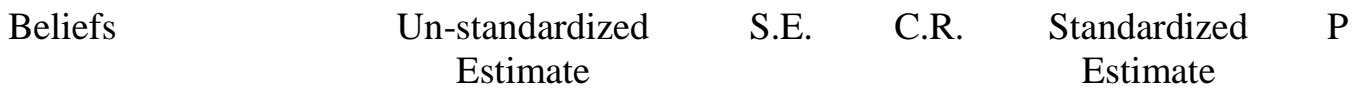

\footnotetext{
PETA refers to a variety of tasks

and situations in which students

can demonstrate their understand ing of the lesson and apply know ledge and skills in a variety of contexts.
}

.392

.031

12.689

.669

PETA is a type of assessment that focuses on demonstration of skills or producing an output.

PETA allows learners to show what they had learned and what they are able to do in diverse ways.

PETA has several forms, such as performance-based tasks, portfolios, journals, diaries, projects, etc.

PETA includes a very wide range of activities such as writing an analysis, conducting laboratory investigations and other related hands-on activities.

PETA requires students to be involved in extensive assessments especially at the formative stage.

PETA is always aligned to standards.

PETA demonstrates alignment of standards by requiring more tasks and work samples.

PETA encompasses many skills and usually has a direct application to real tasks.

.395

$.029 \quad 13.785$

.712

$* * *$

.380

.032

12.065

.644

$* * *$

.030

11.790

.632

$* * *$

$\begin{array}{llll}.369 & .029 & 12.684 & .669\end{array}$

$\begin{array}{llll}.369 & .029 & 12.684 & .669\end{array}$

$12.684 \quad 669$

$* * *$

$\begin{array}{lllll}.330 & .035 & 9.540 & .530 & * * *\end{array}$

$\begin{array}{lllll}.409 & .040 & 10.207 & .562 & * * *\end{array}$

$\begin{array}{lllll}.344 & .040 & 8.691 & .491 & * * *\end{array}$

$\begin{array}{lllll}.436 & .031 & 13.861 & .714 & * * *\end{array}$ 
PETA requires more time to design and evaluate, and more objectivity is needed in scoring.

PETA evidence appears in many different forms; it can involve solving realistic problems, oral or psychomotor skills.

PETA does NOT have exact right or wrong answers. Scores are determined by the teacher through the degrees to which students have achieved or attained the standard or objective.

PETA focuses on the processes and products of learning.

PETA gives feedback to both teachers and students.

PETA scores given to students are not always the same.

PETA implementation is intensive and time consuming.

Small or enabling PETAs are necessary so that the students can perform the culminating PETA proficiently.

Scoring rubrics support learning and is a must in implementing PETA.

The rubric used in scoring PETA identifies all the needed attributes and degrees of completeness of each attribute.

PETA often takes place over time and results in tangible product or observable performance

PETA is interdisciplinary; it can be integrated with other learning areas.

$\begin{array}{llllll}.448 & .032 & 14.209 & .726 & * * * \\ .430 & .034 & 12.827 & .673 & * * * \\ .289 & .037 & 7.875 & .448 & * * * \\ .187 & .044 & 4.234 & .251 & * * * \\ & & & & * * *\end{array}$


S.E.

C.R.

Standardized $\quad \mathrm{P}$ Estimate

I design a PETAs which require

.269 the students to demonstrate the knowledge, skills and values taught to them.

I develop PETAs that make the .308 .025

12.323 .656 class interactive and facilitates exchange of ideas and performances.

I list the knowledge and skills I wish to have students learn as a result of completing a task.

I involve students in the learning process individually or in collaboration with teammates in doing their PETAs.

I only construct performance

.506 achievable.

I develop explicit performance criteria which measure the extent to which students have mastered the knowledge and skills.

I develop performance criteria

that are based on attributes of a product or performance which demonstrate mastery.

I develop checklists that indicate the presence or absence of an attribute which includes how many points each attribute is worth.

I give two - four PETAs during the quarter.

I ask relevant questions about the lesson that can help in

facilitating learning and help students think of better ideas in doing their PETAs.

I give the students the freedom to express their learning in appropriate and diverse ways

I turn the classroom into a in doing their PETAs. 
I do not interrupt or ask

.164

.054

3.065

.183

$* * *$

questions during the students'

presentation of their work.

I give time limit during

.036

7.726

.442

$* * *$

performances or demonstration

of a task.

I always conduct the

5.675

.332

$* * *$

presentation of PETAs inside the

classroom.

I sometimes invite other teachers

.306

.049

6.236

.363

$* * *$

to give grade to the PETAs of

my students.

I always require my students to

.043

$5.803 \quad .340$

$* * *$

use technology in developing

their PETAs

I collaborate with other teachers

teaching other subjects for

.256

$\begin{array}{lll}.043 & 5.916 \quad .347\end{array}$

$* * *$

possible integration of PETAs

I do not let students choose their

own group mates in doing their

PETAs.

I give my feedback on the

$\begin{array}{lll}.054 & 3.786 & .225\end{array}$

$* * *$

students' PETAs such as the

strengths, weaknesses, etc. after

their presentation.

According to Yu-Ching (2008), beliefs are from personal experiences that are transformed into attitudes that influence actions and decisions. In the education context, the domain of teachers ' beliefs is very interesting as there is evidence that teaching, learning and curricula beliefs have a strong influence on their teaching strategies. Borg discusses that teachers' way of thinking and decision making especially in terms of instruction are influenced by their beliefs (as cited in Yu-Ching, 2008). Thus, the study of teacher beliefs provides a means of understanding the relationship between beliefs and insight into teacher classroom practices and pedagogy (Muis \& Foy, 2010; Opre, 2015; Sebate, 2011). However, according to Opre (2015) relationship between beliefs and practices is complex and they influence each other although it may also be possible that beliefs may not usually translate into practices.

Using Structural Equational Model (SEM), a factor loading of .79 was yielded between the beliefs and practices of the respondents, which means that there is a positive correlation between the overall beliefs and practices of the respondents. This result may be likened to the study conducted by Yu-Ching (2008) who tackled the perceptions, beliefs and practices of English as Foreign Language teachers to multiple assessments, which includes classroom observation, paper-and-pencil tests, portfolio assessment, task-based assessments. These types of assessments are all PETAs. The results showed that the relationship between beliefs and practices was positively significant which means that the stronger the beliefs on the multiple assessments of English as Foreign Language teachers have, the more frequently they use this type of assessment in their teaching practices. 


\section{Conclusion and Suggestion}

Senior High School teachers most held beliefs and practices are consistent with the premises of PETAs described by Department of Education and by the literatures reviewed in this study. This shows that teachers implement PETAs that are real life application of learning that requires demonstration of skills or production of an output. Even though this type of assessment is time-consuming to construct, implement, and assess, the respondents apply it in their classes not only because it is mandated by the Department of Education but because they have high beliefs in PETAs being a valid and meaningful way to assess learning.

Although this study involved a large number of respondents, the results of this study may not be very generalizable because the respondents were selected only from private schools. It is therefore recommended that this study be replicated to include respondents from public schools. Future research may also utilize classroom observations as another method of gathering data to verify if respondents' beliefs translate into practices. There might be a difference between respondents' self-reported beliefs and actual practices which could be better revealed through classroom observations. It might also be interesting to investigate if the implementations of PETAs vary across schools and if the manner of implementation is consistent with the mandates of the Department of Education. Lastly, it might also be interesting to investigate to what extent do PETAs serve their intended purposes by examining their effects on the academic performance of the students.

\section{Acknowledgments}

The authors would like to express their gratitude to the University of Santo Tomas Graduate School for all their help and assistance and to the administrators, teachers, colleagues, and friends that had been part of this study for their time and unfailing support.

\section{Conflict of Interest}

The authors declare no conflict of interest.

\section{Funding}

The study was not funded by any institution/ university.

\section{References}

Abbott, A.M., Wren, D.G. (2016). Using performance task data to improve instruction. The Clearing House: A Journal of Educational Strategies, Issues and Ideas, 89(1), 38-45. http://dx.doi.org/10.1080/00098655.2016.1138924

Al-Nouh, N.A., Taqi, H.A., Abdul-Kareem, M.M. (2014). EFL primary school teachers' attitudes, knowledge and skills in alternative assessment. International Education Studies; 7, ( 5). 68-84. http://dx.doi.org/10.5539/ies.v7n5p68

Bachelor, R.B. (2015). Alternative assessments and student perceptions in the foreign language classroom (Doctoral dissertation, Olivet Nazarene University, Illinois, 
USA). Retrieved from

https://digitalcommons.olivet.edu/cgi/viewcontent.cgi? article $=1073 \&$ context $=$ edd diss

Bekiroglu, F.O. (2008). Performance based assessments: theory and practice. Journal of Turkish Science Education 5( 1),113- 131. Retrieved from https://journaldatabase.info/articles/performance based assessments theory.html

Brown T.L., Kennedy, K., Fok, P.,Chan, J., Yu, W. (2009). Assessment for student improvement: understanding hong kong teachers' conceptions and practices of assessment. Assessment in Education: Principles, Policy \& Practice 16 (3), 347363. https://doi.org/10.1080/09695940903319737

Brualdi, A. (1998). Implementing Performance Assessment in the Classroom. ERIC/AE Digest. Retrieved from https://eric.ed.gov/?id=ED423312

Carper, K.J. (2012). Effect of alternative assessments on behavior of students in a secondary art classroom (Master's thesis, Indiana University- Purdue University Fort Wayne, Fort Wayne, Indiana). Retrieved from https://core.ac.uk/download/pdf/47219969.pdf

Department of Education. (2015). Policy guidelines on classroom assessment for the K to 12 basic education program. Retrieved from https://www.deped.gov.ph/wpcontent/uploads/2015/04/DO_s2015_08.pdf

Garcia, M. (2007). The use of scoring on classroom assessment in grade school science instruction proposal for an enriched assessment practice in two selected elementary schools. (Unpublished master's thesis). University of Santo Tomas, Manila, Philippines.

Gonzalez, K. (2014). Alternate assessments for students with profound intellectual delays: understanding the accountability movement from a teacher's perspective. (Doctoral disssertation, University of Florida, Florida, USA). Retrieved from http://ufdcimages.uflib.ufl.edu/UF/E0/04/64/86/00001/GONZALEZ_K.pdf

Guerin.E. (2010). Initial findings from a pilot Italian study of foreign language teachers' stated language assessment knowledge-base and needs. Papers from the Lancaster University Postgraduate Conference in Linguistics and Language Teaching 4, 8-102. Retrieved from http://www.lancaster.ac.uk/fass/events/laelpgconference/papers/v04/LAEL_Volu me4.pdf

Letina, A. (2015). Application of traditional and alternative assessment in science and social studies. Croatian Journal of Education 17(1), 137-151. Retrieved from https://www.researchgate.net/publication/336130446_Application_of_Traditional _and_Alternative_Assessment_in_Science_and_Social_Studies_Teaching

Liu, C.C., Chen, I.J. (2010). Evolution of Constructivism. Contemporary Issues in Education Research. 3(4), 63-66. Retrieved from https://files.eric.ed.gov/fulltext/EJ1072608.pdf

Macblain S. (2018). Learning theories for early years practice. Singapore: SAGE

Publications Ltd. 
Magno, C., Piosang, T. (2016). Assessment schemes in the senior high school in the Philippine basic education. Educational Measurement and Evaluation Review 7, 66-87. Retrieved from https://ejournals.ph/article.php?id=11223

Mcleod, S. (2019). The zone of proximal development and scaffolding. Retrieved from https://www.simplypsychology.org/Zone-of-Proximal-

Development.html\#example.

McTighe, J. (2017). What is a performance task? (part 1). Retrieved from https://blog.performancetask.com/what-is-a-performance-task-part-19fa0d99ead3b

Metin, M. (2013) Teachers' difficulties in preparation and implementation of performance task. Educational Sciences: Theory \& Practice 13(3), 1664-1673. http://10.12738/estp.2013.3.1452

Muis, K., \& Foy, M. (2010). The effects of teachers' beliefs on elementary students' beliefs, motivation, and achievement in mathematics. In L. Bendixen \& F. Feucht (Eds.), Personal Epistemology in the Classroom: Theory, Research, and Implications for Practice (pp. 435-469). http://10.1017/CBO9780511691904.014

Munif, Lukluk \& Fauziati, Endang \& Marmanto, Sri. (2019). Performance assessment: Teachers beliefs and practices in higher education. Journal of Education and Learning (EduLearn) 13(4) 518-526. http://10.11591/edulearn.v13i4.13068

Mussawy, S. A. J. (2009). Assessment practices: student's and teachers' perceptions of classroom assessment. (Master's thesis, University of Massachusetts Amherst, Massachusetts, USA). Retrieved from https://scholarworks.umass.edu/cgi/viewcontent.cgi?article=1008\&context=cie_c apstones

Okabe, M. (2013). Where does Philippine education go? the K-12 program and reform of Philippine basic education. IDE Discussion Paper 425, 1-30. Retrieved from http://hdl.handle.net/2344/1267

Opre, D. (2015). Teachers' conceptions of assessment. Procedia - Social and Behavioral Sciences, 209, 229-233. https://doi.org/10.1016/j.sbspro.2015.11.222

Roach, A., Elliott, S., \& Berndt, S. (2007). Teacher perceptions and the consequential validity of an alternate assessment for students with significant cognitive disabilities. Journal of Disability Policy Studies 18 (3), 168-175. https://doi.org/10.1177\%2F10442073070180030501

Rosaroso, R., Rosaroso N. (2015) Performance-based assessment in selected higher education institutions in Cebu City, Philippines. Asia Pacific Journal of Multidisciplinary Research 3(4), 72-77. Retrieved from http://www.apjmr.com/wpcontent/uploads/2015/11/APJMR-2015-3.4.4.11.pdf

Santrock, J. (2011). Educational psychology (5 ${ }^{\text {th }}$ Ed.). New York, USA: Mc Graw-Hill.

Sebate.P.M. (2011). The role of teacher understanding in aligning assessment with teaching and learning in Setswana home language. (Master's thesis, University of South Africa, Pretoria, South Africa). Retrieved from http://uir.unisa.ac.za/bitstream/handle/10500/5587/thesis_sebate_p.pdf?sequence $=1 \&$ isAllowed $=\mathrm{y}$ 
Stecher, B. (2017). Student performance assessment series: performance assessment in an era of standards-based educational accountability. Retrieved from Stanford Center for Opportunity Policy in Education website:

https://edpolicy.stanford.edu/library/publications/119

Structural Equation Modeling. (n.d). Retrieved from https://www.statisticssolutions.com/structural-equation-modeling/

Tavakol,M. Dennick R.(2011). Making sense of cronbach's alpha. International Journal of Medical Education 2, 53-55. http://10.5116/ijme.4dfb.8dfd

Tria, G,Limpingo, D, Jao,L. ( 2008). Psychology of learning (2 ${ }^{\text {nd }}$ Ed.). Quezon City, Philippines: Ken Incorporated.

Yang, T. (2008). Factors affecting EFL teachers' use of multiple classroom assessment practices with young language learner. English Teaching \& Learning 32(4), 85123. Retrieved from

http://rportal.lib.ntnu.edu.tw/bitstream/20.500.12235/11847/1/ntnulib_ja_B0201 3204_085.pdf

Yu Ching, C. (2008). Elementary school EFL teachers' beliefs and practices of multiple assessments._Reflections on English Language Teaching, 7(1), 37-62. Retrieved from https://www.nus.edu.sg/celc/research/books/relt/vol7/no1/37-62chan.pdf 